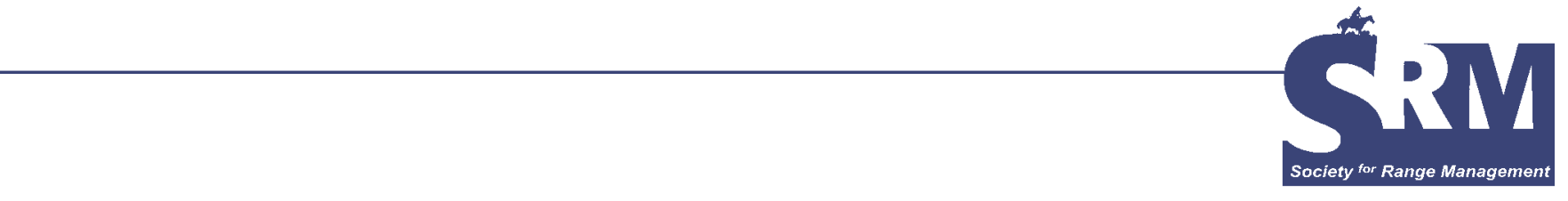

\title{
Introduction: The Working Landscapes Special Issue
}

\section{By Lynn Huntsinger and Nathan F. Sayre}

\section{A}

mericans have long been preoccupied with the idea of nature as pristine and untouched by humans. Conceived as the opposite of - and refuge from-urban areas, this notion of nature overlooks the land in the middle, between city and wilderness. "Working landscapes" gives that place a name and a value by calling attention to the possibility - indeed, the necessity - of effective stewardship and conservation through active human presence and management.

There are several dimensions to this. "Working" means, first, that there is productive activity on the land-such as farming, ranching, or forestry. Ranchers, through the livestock they husband, produce high-quality food, leather, wool, and other livestock products from arid, nonarable places. The term "landscape," meanwhile, connotes a place we look on, and, it is hoped, enjoy looking on. A work of nature is implied, as opposed to a "cityscape," as is a certain expansiveness and, to an ecologist, a large, terrestrial scale. Third, at this scale, there are other things produced by and from the land in a sort of joint production function: intangible things like scenery, tangible things like water, and myriad other things somewhere in between. Landscapes provide habitat for wildlife, sinks for pollutants, and reservoirs of meaning for human communities.

The term "working landscapes" thus carries the weight of a vast and diverse array of "ecosystem services" that humans both rely on and alter for better or worse. In this sense, it proposes as an ideal the synergistic combination of commodity production with the provision of public benefits of various kinds. How do we accomplish this both as a quality of life for us and as a legacy for future generations?

This article has been peer reviewed.
A significant portion of the western states are public lands managed by public agencies. It might be assumed that having $50 \%$ of California as public land or $90 \%$ of Nevada is enough-yet here we are proposing that private working landscapes are worthy of further public and private expense and effort to protect. However, private lands are ecologically different from public lands, as Colin Talbert, Richard Knight, and John Mitchell demonstrate in this issue. In addition, public and private lands are connected by the ranching enterprise, and conservation of private lands is therefore linked to the policies and decisions of public land managers, as revealed in Adriana Sulak and Lynn Huntsinger's article.

On rangelands, ranching is the key to conserving working landscapes. Ranchers throughout the West are besieged by low income from production and inflated real estate valuesseveral of the articles herein discuss this problem. A working landscape requires a worker. Ranchers like to produce livestock products, but the ecosystem services they also produce are becoming valuable to today's society. How can this value be harnessed to support and motivate the worker and thereby support working landscapes? Conservation easements are one method, and two of the articles in this issue are devoted to the topic. Anthony Anella and John Wright lay out the many options that easements offer the rancher. Adena Rissman, Richard Reiner, and Adina Merenlender describe the way that easements are monitored and how the relationship with the easement holder can be a long-term, collaborative process.

The stewardship of ranchers, past and present, shapes the capacity of the land to produce livestock and ecosystem services. In California, recent research has demonstrated significant ecological values from grazing in addition to the obvious benefit of maintaining open, natural landscapes. The California Rangeland Coalition, described by Sheila Barry, Tracy 
Schohr, and Karen Sweet, is an effort to build collaboration between environmental groups, ranchers, and agencies to protect working landscapes and support good land stewardship. Bill McDonald and the Malpai Borderlands Group (http:// www.malpaiborderlandsgroup.org) made history when they developed a collaborative management program with agencies and ranchers and initiated a grass bank program in 1994. Since then, several grass banks have emerged in the West, as reported in Rangelands (27:24-28) by Stephanie Gripne in 2005. Courtney White and Craig Conley update us on the Valle Grande Grassbank, a creative and collaborative effort to conserve New Mexican working landscapes, and give us some things to ruminate on as we contemplate the future of grass bank programs.

The ability to respond to change is crucial as we look to the future of working landscapes. Carrie Kennedy and Mark Brunson examine the capacity for innovation in ranching communities and the factors that influence that capacity. The article illuminates how educational outreach and personal relationships (with other ranchers as well as agency personnel) can enhance ranch sustainability by influencing the outlook and information base of ranchers. In fact, ranchers have a long history of coping with changes in policy, environment, markets, science, and social attitudes. Nathan Sayre's article illustrates the rich history of rancher interactions with the land and describes the motives and outside influences that have affected those interactions in the Altar Valley of Arizona.

Finally, the phenomenon of a "working landscape" is nothing new. Native Americans were shaping western landscapes long before the arrival of European settlers. Unfortunately, their knowledge of western ecosystems and skill at managing them were long ignored and their practices suppressed. Lucy Diekman, Lee Panich, and Charles Striplen discuss Native American working landscapes in California and illustrate the importance of traditional knowledge and working with tribes. Many ranchers also feel that their knowledge and their practices are too often misunderstood and ignored. Can we build a science that respects the traditional and local knowledge that comes from working in and with a landscape?

Initially, many ranchers were reluctant to think that they might be in the business of producing ecosystem services as well as producing livestock. Today, the pendulum has swung in the other direction, with increasing identification of ecosystem services from ranchland, and research that shows us how to use livestock to create ecological benefits and minimize negative impacts. However, the identification of an ecosystem service does not create a market or a way to compensate or incentivize the production of the service by ranchers. Mechanisms need to be found to reward ranchers for good stewardship that provides public benefits, mechanisms that in turn help the rancher stay in business.

"Perpetuity," a stipulation on conservation easements, is an aspiration at best, but it makes some ranchers nervous. In theory, perpetuity assures public investors that the benefits they pay for through easement purchase or tax relief will be around for the long term. Other forms of investment in ranchers' land or practices cannot promise such long-term returns. Pressures for ranchers to sell land are powerful in many places - often those places with exceptionally high ecosystem service values. There are a variety of incentive programs for wildlife habitat enhancements and investments to improve management-but the likelihood that properties will someday be developed undermines these public investments. In the European Union, by contrast, agriculturalists are often well compensated for ecosystem services they produce. However, European agricultural producers are generally not free to develop their land or sell it for development. Will the American public demand a similar trade-off? In fact, conservation easements embody this public desire. Conservation easements work for donors and the public, in part, because they help solidify the tenure of the ranch.

There are many dimensions to working landscapes, and with this issue we have been able to explore only a few. Ideally, we would have articles by ranchers and agency managers; we would have talked more about land trusts and the important role they will play in the future, and we would have reported on some of the very impressive land trusts working in our own backyard, notably the pioneering and always interesting Marin Agricultural Land Trust (http://www.malt. org). In a recent survey conducted in California, rangeland landowners reported that they asked land trusts for advice as often as they did advisory agencies. We hope that some of you will contribute more articles about the diverse aspects of working landscapes to future issues of this journal.

Finally, there will always be room for change, innovation, and improvement in grazing management on working landscapes. As we learn more about ecosystems and how they work and as social and environmental needs change, there will also be a need for changes in management. Not every rancher is the steward we might desire, although a great proportion of them regularly demonstrate their commitment to the land and to doing the best they can despite all the obstacles. We face huge challenges when it comes to transitioning to the next generation of ranchers and making sure that ranchers can survive economically. But when it comes to conserving western landscapes and the cultures and environments that make the West unique, we must not "let the perfect be the enemy of the good." Management problems can be fixed, easement terms can be negotiated, regulations and incentives can be crafted, and other creative approaches to conservation can be found. There are plenty of options for improving and restoring working landscapes as long as they are not under asphalt.

Authors are Associate Professor, Environmental Science, Policy, and Management, 137 Mulford Hall MC 3114, University of California,Berkeley, CA 94720-3114,buckaroo@nature. berkeley.edu (Huntsinger); and Assistant Professor, Department of Geography, 507 McCone Hall MC 4740, University of California, Berkeley, CA 94720- 4740 (Sayre). 